DOI 10.31558/2519-2949.2020.4.6

УДК 323:343.4

ORCID ID: https://orcid.org/0000-0002-2822-2268

Ягунов Д. В., Донецький національний університет імені Василя Стуса

\title{
ТОРТУРИ ЯК ІНСТРУМЕНТ СУЧАСНОЇ ПОЛІТИКИ СОЦАЛЬНОГО КОНТРОЛЮ
}

Стаття присвячена дослідженню феномену тортур у XXI столітті. У статті автор презентує тезу, щз пояснює не лише відновлення тортур як феномену у другій половині XX століття, проте й на додаток - поширення цього феномену тортур у XXI столітті, де особливого значення набувають питання щодо "розкидування» мереж сочіального контролю та, як наслідок, збільшення класів, типів та видів девіантів. Так, з одного боку, національні системи кримінальної юстииії не можуть впоратися з таким завданням - поводитися з девіантами виключно у рамках формальних процедур, закріплених у національному законодавстві на фоні збільшення класів, типів, видів та, як наслідок, кількості девіантів. 3 іншого боку, дані численних досліджень та опитувань населення країн Свропи та Північної Америки, де від 1/3 до 1/2 громадян допускають застосування тортур до терористів з метою того самого «убезпечення». У статті робиться висновок, що політика запобігання катуванням та боротьби з соиіальними практиками катування у ХХІ столітті - це відображення складного політичного дуалістичного прочесу: спроба ще більшого "убезпечення суспільства» з одночасним фіаско такого «убезпечення». У статті проаналізовано моделі, які пояснюють політичні передумови застосування тортур у другій половині XX - початку XXI столітті для цілей «захисту суспільства». Так, вченими виділяються три моделі: 1) «security model»; 2) «stability model»; 3) «legitimacy model». У статті наголошується, що в суспільстві ХХІ століття тортури існують у рамках двох взаємопов'язаних політичних сфер, де однією зі сфер виступає формалізована суб'єктна політика протидії тортурам, ще формується та реалізується у рамках універсальних регіональних та начіональних структур, а другою сферою виступає безсуб'єктна політика тортур, яка формується у рамках постсучасної модуляиії паноптичного менеджменту ризиків, де тортури є інструментом сучасної політики соціального контролю.

Ключові слова: катування, нелюдське поводження, Свропейський суд з прав людини, Конвенція про захист прав людини, Комітет запобігання катувань, Рада Європи, «посиленні методи допиту», запобігання катуванням, розслідування катувань, передумови катувань у ХХІ столітті.

Проблема, що аналізується у цій статті, пов'язана з соціальним феноменом тортур та політичними передумовами його поширення у XXI столітті.

Головна авторська теза статті полягає в тому, що у XXI столітті тортури стали категорією не скільки юридичної, стільки політичної науки, формуючи важливу частину сучасного політичного дискурсу взаємовідносин влади і соціуму, ігнорувати який не уявляється можливим.

Автор здійснив спробу довести, що тортури, формально заборонені універсальними й регіональними стандартами прав людини, національним законодавством держав, що позиціонують себе демократичними (особливо країн - членів СС та Ради Свропи), у XXI столітті $є$ прихованим інструментом політики соціального контролю, що формується поза формальними нормативними рамками i, що є більш важливим, нерідко безсуб'єктно. Відтак, саме політична наука має більший потенціал щодо глибшого дослідження феномену тортур, а також передумов та причин його поширення.

Проблематика боротьби з практиками катування знайшла своє відображення у дослідженнях таких вчених як В. Гацелюк, О. Гумін, В. Батчаєв, А. Замула, Є. Захаров, Д. Кобзін, М. Коваль, Р. Мигаль, О. Михайлик, М. Пузирьов, П. Пушкар, А. Савченко, Ю. Таволжанська, М. Хавронюк, А. Черноусов, С. Щербань та багатьох інших вчених. Проте здебільшого зазначені питання аналізувалися з погляду юридичної науки. Відповідно ця стаття $є$ продовженням наукових розвідок автора, здійснених в контексті політичної науки [1]. 
Підсумовуючи деякі раніше сформульовані висновки, слід зауважити:

1) є більш ніж дискусійною поширена теза, що тортури як соціальний феномен, як частина системи кримінальної юстиції та як елемент відносин влади «зникли» наприкінці XVIII - початку XIX ст. ст. внаслідок «гуманізації», хоча, з іншого боку, не можна заперечувати суттєвий вплив гуманістичних ідей, спрямованих проти права легітимізованого насильства, присвоєного собі державою та церквою у XII - XIII ст. ст., реалізація якого тривала 3 достатньо великим розмахом (водночас багато науковців піддають сумніву масштаби такого легітимізованого насильства з боку церкви та держави $[2 ; 3 ; 4 ; 5 ; 6 ; 7 ; 8]$.

2) на більшу увагу заслуговують погляди науковців, які доводять тезу, що тортури залишались перманентним елементом відносин влади навіть у другій половині XIX - першій половині XX ст. ст., що мало місце у завуальованих формах в силу формальної заборони тортур, закріпленої на рівні національного законодавства держав того часу;

3) феномен катування було відроджено у колосальних масштабах тоталітарними політичними режимами у середині XX століття з метою фізичного знищення цілих прошарків населення та насадження атмосфери страху в суспільстві;

4) у XXI столітті мала й продовжує мати місце тенденція розширення застосування тортур у ще більш завуальованих формах для цілей здійснення соціального контролю у відносинах влади i суспільства Постмодерну, що особливо проявилося на прикладі деяких ліберальних демократій у глобальній «War on Terror» після подій 11 вересня 2001 року [9]. Застосування тортур до девіантів, злочинців, «терористів» та «небезпечних осіб» $є$ поширеною практикою навіть у західних країнах, не зважаючи на те, що розгалужена система формальних правових гарантій, створена у другій половині XX століття і розвинута на початку XXI століття, допомогла зробити практики катувань та нелюдського поводження максимально рідким явищем, наскільки це можливо (на європейському регіональному рівні - завдяки Раді Європи, Комітету з запобігання катувань та Європейському суду 3 прав людини).

Таким чином, незважаючи на формальне перебування катування поза національним законом, а головне - поза універсальними та регіональними стандартами прав людини, катування сьогодні існує як інструмент політики соціального контролю та широко використовується як соціальна практика, дослідження чого потребує не стільки вузького юридичного аналізу поняття катування як формальної дефініції, скільки дослідження цього феномену крізь призму політичної науки з метою віднайти відповідь на питання: які політичні фактори сприяють поширенню практики катування у майже всіх країнах сучасного світу на фоні універсальності концепції прав людини та активної реалізації політики із запобігання катуванням.

У контексті нашого дослідження ця політика має негативну конотацію, що не виключає іiі існування як об’єктивної складової сучасних відносин влади навіть за відсутності конкретних суб'єктів такої політики. Незважаючи на свою формальну легітимність та «нормальність» для Середньовіччя, принципово важливим тут є те, що відобразила Л. Трейсі: «Катування було симптомом нестабільності як у період Середньовіччя, так і в ранній Новий час» [7, с. 249]. Відповідно, катування у XXI столітті- це подвійна політична нестабільність, або політична нестабільність, доведена до крайньої межі.

У нашому попередньому дослідженні феномену тортур XXI століття ми виокремили три групи факторів, що вплинули на зникнення формалізованих тортур як засобу доказування у кримінальному процесі та виду покарання у відносинах влади наприкінці XVIII - початку XIX ст. ст., а головне - як легітимізованої суб'єктної політики: 1) класично-філантропічний; 2) прагматичний; 3) дисциплінарний [1].

Визнаючи кумулятивний ефект усіх трьох факторів, автор вважає за потрібне досліджувати соціальні практики тортур саме в якості інструменту безсуб'єктної політики у контексті впливу зазначеного вище «дисииплінарного» чиннику, що обумовив відхід політики від ії суб 'єктної форми, що демонструє право на використання сили (iї легальних і легітимізованих інструментів) та «розчинив» тортури усередині дисциплінарно-карцерних механізмів здійснення влади.

Саме цей підхід, який сформулювали німецькі вчені Георг Руше та Отто Кіркхеймер, а також французький філософ Мішель Фуко, і якого ми здебільшого дотримуємося у нашому дослідженні, пояснює «зовнішнє» зникнення тортур тим, що для цілей соціального контролю в умовах капіталізму, що народжувався та набирав обертів, методи «дисциплінування» капіталістичного суспільства та розкидування соціально-контрольних мереж були набагато кращими та економічно більш вигідними, аніж жорсткі формалізовані публічні процедури, спрямовані проти тіла, яке у часи Середньовіччя 
нерідко було єдиною власністю людини. Якщо у часи Середньовіччя саме публічні катування та фізичні покарання символізували та демонстрували владу государя або феодала, то з початку XVIII століття численні методи соціального контроля та нагляду паноптичної природи відносно швидко витіснили жорстокі тілесні каральні практики $[10 ; 11]$. Все це знаменувало остаточне завершення епохи панування I модуляції соціально-контрольних практик- модулящії бінарної законності (за визначенням М. Фуко). Водночас саме цей період відповідав початку II модуляції модуляції дисиииліни.

М. Фуко грунтовно пояснює причини переходу від «законності» до «дисиипліни» через те, що влада, для якої суверенітет був модальністю, виявилася недостатньою для управління економікою і політичними процесами в суспільстві, що переживало демографічний вибух та індустріалізацію. Наголосимо, що так само функиіональність пояснює виникнення начебто «виправної» в'язниці як виду та місця покарання: застосовування тортур припинилося не тому, що це перестало вважатися гуманним, а лише тому, що це стало економічно невигідно: «Hото penalis, тобто людина, яка карається законом і яка може бути покараною законом, цей homo penalis [насnравдi] . . є с homo economicus» [12, c. 312]. Проте, водночас, це не означає, що катування зникли: вони лише «відійшли у тінь», зберігши статус та значення важливого засобу соціального контролю.

Попередньо автор, вивчаючи політику запобігання тортур, наводив численні приклади поширення катувань як соціальних практик майже в усіх сучасних країнах, причому подібна картина спостерігається упродовж всього початку XXI століття [1]. Відповідні висновки продемонстрували численні соціологічні дослідження, проведені такими міжнародними організаціями, дослідними центрами та засобами масової інформації як Amnesty International, Gallup, ABC News Polling Unit, Pew Research Center, Chicago Council on Foreign Relations, Fox News, ABC News, Washington Post, Pew Research Center, Associated Press, Ipsos-Public Affairs Harris Interactive, CBS News, New York Times, Pew Research Center, PIPA/Globescan, YouGov [1]. Як засвідчили зазначені дослідження, від 1/3 до 1/2 населення США, Канади та країн Свропи підтримують застосування тортур проти «терористів» 3 метою отримання інформації задля досягнення певного «соціального блага» або в інтересах певної «соціальної необхідності» у загрозливих або екстремальних політичних умовах. Причому найбільший запит на тортури спостерігається саме у політично нестабільних країнах (Близький Схід, Африка тощо).

Водночас опитування, проведені упродовж останніх років Amnesty International та International Committee of the Red Cross, констатують, що приблизно 1/2 респондентів з різних країн світу відчувають страх бути підданим тортурам у випадку взяття їх під варту [13]. Щодо України, то за даними дослідження Харківського інституту соціальних досліджень та Харківської правозахисної групи, оціночна кількість жертв побиття та завдання тілесних ушкоджень у ході затримання поліцією у період $2004-2018$ років в Україні складала від 1 млн. осіб у 2004 році до 0,5 млн. осіб у 2018 році [14]. Причому у 2020 році оціночна загальна кількість жертв незаконного фізичного насильства в поліції України становила 0,7 млн. осіб. Водночас 52\% респондентів в Україні, опитаних у 2020 році, вказали, що вважають такі випадки розповсюдженими, а 12\% - дуже розповсюдженим [15].

Отже, коли майже половина населення усіх держав світу (навіть країн Європи) має страх бути підданим тортурам у випадку затримання поліцейськими, взяття під варту або поміщення до пенітенціарної установи, проте водночас вимагає більшого застосування тортур, то подібний дуалізм надає підстави постулювати, що «гуманізація» дійсно не була домінуючим політичним фактором, який обумовив «маскування» соціальних практик катувань. Так, М. Фуко додатково доводить: теза про те, що «гуманізація» «врятувала» девіантів та злочинців від тілесних страждань $\epsilon$ помилковою, адже правосуддя періоду Середньовіччя переслідувало тіло навіть після смерті «поза межами всякого можливого страждання».

Отже, існують підстави зробити наголос на аспекті, який має принципово важливе значення для цілей політики запобігання катуванням: стереотип, щчо у XXI столітті завдяки «гуманізачії соиіальних відносин» тортур стало менше, є небезпечним для цілей політики запобігання тортур.

Досліджуючи трансформацію модуляцій покарання («законність»- «дисципліна» - «безпека»), М. Фуко робить важливий наголос: процес переходу від середньовічної кримінально-правової тілесної корпоральності до сучасної модуляції покарання «занадто поспішно і категорично пояснили проиесом «гуманізаиї̈», відмахнувшись тим самим від необхідності подальшого аналізу». Так само, політичний аналіз сучасних національних систем кримінальної юстиції у категоріях більшої гуманізованості, результативності та прогресивності створює негативні передумови для політики 
запобігання та розслідування випадків тортур, коли в основі такої превентивної діяльності лежить міф гуманізації, що приховує справжні причини тортур як політичного феномену.

Формальний підхід, що ми згадали вище, з його ключовою категорією «гуманізаиії» не може пояснити ще більше поширення катувань у XXI столітті. Тим не менш, феномен катування - це об'єктивна реальність, яку не можна ігнорувати в процесі політичного аналізу сучасних відносин влади. Відтак, беручи до уваги поширеність феномену катування навіть у майже усіх країнах світу, а головне - політичний запит на застосування нелюдського поводження, можна постулювати наявність певної політики безсуб'єктної катувань, у рамках формування якої соціальні практики катування розглядається якщо не інструмент, то принаймні передбачуваний побічний результат (хоча ми, як це вбачається з назви статті, схильні до категорії «інструменту»).

Обгрунтовуючи природу політики катувань у часи Середньовіччя, М. Фуко робив особливий акцент, що жорстокі каральні страти із застосуванням тортур являли собою «диференційоване спричинення страждання, організований ритуал таврування жертв і презентацію караючої влади», проте аж ніяк не «озлоблення правосуддя, яке, забуваючи свої принципи, карає без упину». У надмірності тортур була закладена «иіла економія влади». Розвиваючи цю тезу М. Фуко, ми наголошуємо, що безсуб'єктна політика тортур XXI століття - це аж ніяк не масштабний ексцес виконавців, які реалізують владні повноваження усфері боротьби зі злочинністю або у сфері «глобальної війни з тероризмом», а натомість цілий пласт складних багаторівневих політичних та економічних зв'язків, які здебільшого перебувають поза межами впливу юриспруденції та відповідних формальних процедур.

Усталеним поглядом соціологів та кримінологів на проблематику злочинності $\epsilon$ те, що злочинність є нормальним явищем для будь-якого суспільства, проте - наголосимо - у певних обсягах та проявах. Завелика концентрація девіантності та злочинності - це ознака аномії, на що вказували Е. Дюркгейм та Р. Мертон [16, с. 136]. Відтак, з огляду на поширення практики катувань у XXI столітті, коли кожен другий громадянин планети має небезпідставні ризики бути підданий тортурам у поліцейській дільниці, слідчому ізоляторі або в'язниці, випливає важлива теза: проблема поширення тортур у суспільстві XXI століття не $\epsilon$ виключно правовою та кримінологічною проблемою, яка може бути вирішена запровадженням нових або вдосконаленням вже існуючих міжнародних стандартів прав людини та дією відповідних національних законів. Більш важливими $€$ політичні, економічні та моральні аспекти передумов поширення феномену тортур, що надає підстави говорити про насичення соціальних відносин практиками катування внаслідок певної політики, яка за певних умов формується навіть за відсутності суб 'єкта.

У цій нашій статті акцент робиться на тому, що катування наразі широко використовується у відносинах влади різними політичними акторами, де у політичному обігу перебуває гнучка та, відповідно, небезпечна з огляду на стандарти прав людини «формула заборони тортур» - «absolute in principle but relative in application». Причому, наприклад, для американського політичного поля запроваджено категорично неприйнятний для європейської політики висновок, що «регулювання застосування тортур краще, аніж заборона» [17, с. 614].

Проте навіть, на перший погляд, нейтральні або навіть просоціальні політичні ініціативи, стратегії та проекти у суспільстві XXI століття опосередковано зумовлюють використання катувань через певні форми ланцюгових реакцій, що головним чином пов'язане 3 хвильовими кампаніями «боротьби зі злочинністю», спрямованими на підвищення рівня розкриття злочинів (чим здебільшого характеризуються пострадянські країни), а також зі згаданим вище збільшенням видів, типів та класів девіантів у сучасних суспільствах внаслідок «moral panic» перед «загрозами злочинності».

Надаючи авторське обгрунтування поширення феномена тортур у XXI столітті, розвиваючи модулярну концепцію Мішеля Фуко, концепцію «пунітивного міста» Стенлі Коена, автор використовує власну концепцію переходу сучасних суспільств до IV модуляції соціальноконтрольних та каральних практик- постсучасної модуляиії паноптичного менеджменту ризиків [18, с. 146]. Так, на нашу думку, саме «убезпечення суспільства» є ключовою тезою, яка пояснює поширення феномену тортур у XXI столітті на фоні задекларованої нульової толерантності до таких соціальних практик. Тому, наслідуючи підхід М. Фуко і С. Коена до «поширення дисципліни», «розкидування мереж» та «управління злочинністю» у капіталістичному суспільстві, а також підхід Е. Гідденса щодо «островів безпеки» у сучасному суспільстві, наголошуючи, що тортури не зникали як соціальне явище навіть у другій половині XX століття, як це стверджується у рамках класичного підходу, ми постулюємо, що тортури з боку державних агентів та представників політичних еліт були й залишаються сферою особливого управління, що надає підстави підтримати 
думку багатьох західних авторів щодо тези про «managing torture». Зовнішнім проявом «managing torture» $\epsilon$ напівлегалізація тортур, яка з другої половини XX століття отримали назву «еnhanced interrogation techniques».

Невидимість тортур не означає відсутність таких соціальних практик, через що будь-який політичний режим намагається контролювати населення (особливо ті, прошарки, які вважаються небезпечними або принаймні «ненадійними» для функціонування такого режиму), де тортури можна вважати свого роду «побічним продуктом» механізмів соціального контролю, таким собі «ексцесом виконавиів нижчої ланки» у процесі «убезпечення суспільства», у той час коли вищі ланки, як раз навпаки, активно декларують пошук нових, більш дієвих та сучасних формальних методів протидії катуванням.

Відтак, з огляду на практику поширення феномену катувань у сучасному світі, теза про «managing torture» у рамках безсуб'єктної політики тортур заслуговує на велику увагу. У цьому ж контексті цікавим $є$ наступне визначення: «Катування - це організація застосування (administration) сильного болю чи страждань фізичних чи психічних, з певною метою, наприклад, для отримання зізнання, здійснення контролю, нагнітання страху, покарання або з будь-якої іншої причини на підставі дискримінації будь-яких виду» [19].

Говорячи про поширення феномену тортур у XXI столітті, потрібно зробити базовий акцент: зазначений феномен не може існувати без соціальної підтримки громадян сучасних суспільств, які віддають свою свободу в обмін на «безпеку суспільства». В умовах, користуючись термінологією Ульріха Бека, «суспільств безпеки», коли «свобода» розчинилася у мережах «убезпечення», «захисту суспільства» та «gated communities» і коли кожна політична криза актуалізує питання ще більшого «захисту суспільства» від «загроз злочинності», «нелегальної міграції» та «тероризму», процес завуальованого стимулювання застосування тортур та навіть легалізації тортур набирає нових обертів, набуваючи ще більших ознак політики з тенденцією до подальшої формалізації та суб 'єктності.

Американський вчений Кристофер Ейнольф слушно зазначає, що в процесі історичного розвитку катування найчастіше застосовувалося проти людей, які не $\epsilon$ повноправними членами суспільства, таких як раби, іноземці, військовополонені та представники расових, етнічних і релігійних аутсайдерів. Набагато рідше катування застосовувалося проти членів або громадян суспільства. Катування частіше застосовуються, коли уряд або суспільство сприймає себе під загрозою [20, с. 106]. Відкреслюючи наукову цінність зазначеної тези, ми вважаємо, що зазначений погляд повністю кореспондує науковим поглядам Зігмунта Баумана та Ульріха Бека щодо сучасних «сусnільств ризиків» та розподілу населення на глобалізованих «туристів» та локалізованих «бродяг», де останні розглядаються як такі, що демонструють явні або приховані «ризики», і від яких суспільство потребує «убезпечення» - нехай навіть у найбільш радикальних формах.

Передумови зазначених поглядів були сформульовані німецькими вченими Отто Руше і Георгом Кіркхеймером ще 1939 року в їх класичній праці «Punishment and Social Structure», де вчені зробили важливий акцент, чому тортури у пізньому Середньовіччі отримали більшу легітимність та поширення: чим біднішими ставали окремі категорії осіб, тим більш загрозливими вони вважалися для суспільства. На аргументовану думку Руше і Кіркхеймера, соціальні та економічні умови в Свропі, що спричинили масове зростання кількості матеріально знедолених осіб, спричинили дедалі більш авторитарні заходи соціального контролю, включаючи процедури та подальші покарання, які мало приділяли уваги питанням винності або невинуватості [21]. Усіх, хто залишився без даху над головою або мав низький соціальний статус, потрібно було максимально контролювати у будь-який спосіб та будь-якою ціною. У цьому контексті можна згадати англійські «закони про бідних» (Роог Laws), які формально вони мали чинність до 1948 року [22]. Навпаки, купці та інші заможні особи могли уникнути загрози катувань саме в силу їхнього матеріального стану. Саме cmamyc, а не окремі дії, був головною, якщо не єдиною різницею стосовно ризику застосування тортур як засобу отримання доказів і тортур як покарання.

Сьогодні ми маємо тих саме глобалізованих «туристів» та локалізованих «бродяг», проте проблема, нехай будучи значно завуальованою, залишається по суті такою ж, як і в часи Середньовіччя. Так, лише у січні 2021 року Європейський суд 3 прав людини висловився 3 приводу жебрацтва та людської гідності в справі «Lacatus v. Switzerland», де заявниця, громадянка Румунії з ромської громади, неписьменна та безробітна, без соціальної допомоги, жебрувала під час перебування у Швейцарії. Ї̈ї визнали винною у кантоні, де жебрацтво заборонене, і засудили до штрафу або 5 днів позбавлення волі у разі несплати, що згодом було визнано порушенням статті 8 Конвенції про захист прав людини [23]. 
У попередній нашій статті щодо проблематики тортур ми аналізували моделі, які пояснюють політичні передумови застосування тортур у другій половині XX - початку XXI столітті для цілей «захисту суспільства» [1]. Так, вченими виділяються три моделі: 1) «security model»- тортури як інструмент, який начебто дійсно може підвищити захист суспільства від загроз, що постають перед суспільством (зокрема для отримання від терористів або членів організованих злочинних угруповань інформації про вчинені терористичні акти або інші тяжкі злочини, а так само, як про такі, що плануються або вже приводяться у виконання (the 'ticking bomb' argument)); 2) «stability model»тортури як інструмент завуальованого державного терору для «дисциплінування» населення та придушення потенційного або фактичного політичного протистояння, яке може загрожувати інтересам політичних еліт; 3) «legitimacy model» - тортури як спосіб декларування окремими особами та/або політичними елітами «права назастосування катування» задля власних інтересів, де зовнішнім обгрунтуванням $€$ «інтереси суспільства» або навіть «всього світу» та захист таких інтересів від «тероризму» та «організованої злочинності».

Звичайно, кордони між зазначеними вище моделями є умовними, хоча не можна не визнати великий ступінь автономності кожної із запропонованих моделей. Більше того, можна вважати, що саме у своєму кумулятивному ефекті зазначені моделі пояснюють передумови та причини поширення феномену тортур у XXI столітті, надаючи цілісну картину.

Слідуючи модуляційній концепції М. Фуко та проводячи відповідну аналогію, ми вважаємо за потрібне на додаток продовжити думку американського дослідника Р. Блейклі, що більшість тортур з боку агентів держави мають мало спільного із захистом населення від неминучих загроз безпеці. Набагато більше вони пов'язані з подоланням загроз інтересам елітних груп, більшість 3 яких мають транснаціональну природу та відповідний політичний вплив [24, с. 381].

Відтак ми можемо сформулювати власну позицію з приводу природи тортур, які сьогодні застосовуються агентами держави, яка кореспондує поглядам Стенлі Коена, Мішеля Фуко, Ульріха Бека та Зігмунта Баумана, щодо глобалізованих «туристів», локалізованих «бродяг» та насичення політичного тіла суспільства «безпекою» з метою ще більшого соціального контролю над кожним рухом та навіть - станом на сьогодні - кожною думкою пересічного громадянина.

Політичні еліти та приватні транснаціональні корпорації насичують суспільство важливими для відносин влади мессиджами: так, тортури, це більш ніж огидно. Проте світ змінився настільки, що перед суспільством стоїть принциповий вибір: або пожертвувати одним терористом, або допустити загибель сотень або тисяч безневинних людей. Поставивши суспільство у стан вкрай непростого вибору, політичні еліти та пов'язані з ними приватні транснаціональні корпорації декларують, що відмова від застосування катувань щодо небезпечних злочинців та терористів може компенсуватися мінімум трьома речами: 1) збільшенням фінансування поліції та служб безпеки; 2) ще більшим насиченням суспільства камерами відеоспостереження та іншими пристроями спостереження; 3) ще більш вільним та несанкціонованим доступом агентів держави до персональних даних громадян «заради їх власної безпеки». Як наслідок, створюються додаткові умови для більшої концентрації паноптичної «дисципліни» у політичному тілі суспільства та, як наслідок, набуття ним ознак карцерного суспільства. Іншими словами, йдеться про те, тортури стають свого роду інструментом політичного шантажування, де під гаслами абсолютної заборони тортур політичні еліти отримують для себе ще більше бонусів для цілей реального вторгнення до «свободи» суспільства та кожного окремого громадянина.

Щодо «legitimacy model», то в цьому контексті необхідно наголосити на важливому, як на нашу думку, аспекті. Так, після оголошеної у вересні 2001 року «War on Terror» США та інші демократичні країни взяли курс на легалізацію застосування тортур, створюючи декларативне політичне протистояння - «глобальне зло» проти «глобального рятівника світу», де з'єднувальною ланкою стала легітимізація катувань під виглядом enhanced interrogation techniques. У подальшому процес легітимізації спрощується, коли з формули «глобальне зло» проти «глобального рятівника світу» прибираються слова «глобальне» та «світу». Саме у цьому, як на нашу думку, криється головна небезпека будь-якої легітимізації тортур як соціальних практик.

Підсумовуючи викладене вище, автор презентує тезу, що пояснює не лише відновлення тортур як феномену у другій половині XX століття, проте й на додаток - поширення цього феномену тортур у XXI столітті, де особливого значення набувають погляди Мішеля Фуко та Стенлі Коена щодо розкидування мереж соціального контролю та, як наслідок, збільшення класів, типів та видів девіантів, яких потрібно контролювати для цілей того самого «убезпечення».

Так, з одного боку, національні системи кримінальної юстиції не можуть впоратися 3 таким завданням - поводитися 3 девіантами виключно урамках формальних процедур, 
закріплених у національному законодавстві на фоні збільшення класів, типів, видів та, як наслідок, кількості девіантів.

3 іншого боку, самі громадяни, народжені у часи III та, що є більш важливим, IV модуляції соціально-контрольних практик, в обмін на свою «свободу» вимагають ще більшого «убезпечення», де для них вже не мають значення шляхи та методи досягнення відповідної «концентрації безпеки». Як зазначалося вище, підтвердженням цього є дані численних досліджень та опитувань населення країн Європи та Північної Америки, де від третини до половини громадян допускають застосування тортур до терористів з метою того самого «убезпечення». Причому це все відбувається на фоні тотального соціального контролю за простором, рухами та думками з боку держави, політичних еліт та могутніх приватних акторів. Проте головним $€$ те, що практична можливість застосування тортур до «терористів» 3 метою отримання відомостей про подальші терористичні акти відкриває «скриньку Пандори», де з'являється широка та водночас вкрай небезпечна перспектива застосування катувань проти інших «небезпечних злочинців»- колаборантів, dangerous offenders, persistent offenders, sex offenders, членів організованих злочинних угруповань тощо. Причому цей список має явну небезпеку піддаватися розширенню.

Можна зробити висновок, що політика запобігання катуванням та боротьби з соціальними практиками катування у XXI столітті- це відображення складного політичного дуалістичного процесу: спроба ще більшого «убезпечення суспільства» з одночасним фіаско такого «убезпечення».

Необхідно зробити особливий наголос: тортури - це не юридична категорія, проте, у першу чергу, політична. Аналіз феномену катувань лише у формальних рамках національних систем кримінальної юстиції $є$ небезпечним не лише для самих жертв катувань, а також для тих, хто застосовує катування, особливо беручи до уваги вельми сумнівну результативність та ефективність катувань, відповідальність за які покладається згодом саме на платників податків, які нерідко вимагають «більмої безпеки»- навіть з використанням найбільш огидних інструментів, якими $€$ катування та інші форми нелюдського поводження.

Проте головним висновком цієї статті буде те, що, на відміну від юридичної науки, тортури крізь призму політичного аналізу - це об'єктивний елемент сучасних політичних відносин. Тортури невід'ємна складова відносин влади та водночас побічний продукт поширення дисципліни паноптичного зразку в суспільстві XXI століття.

Підводячи підсумки, ми може сформулювати наступне: у суспільстві XXI століття тортури існують у рамках двох взаємопов'язаних політичних сфер, де однією зі сфер виступає формалізована суб'єктна політика протидії тортурам, що формується та реалізується у рамках універсальних регіональних та національних структур (ООН, Рада Європи, ЄСПЛ, КЗК тощо), а другою сферою виступає безсуб'єктна політика тортур, яка формується у рамках постсучасної модуляції паноптичного менеджменту ризиків, де тортури $є$ інструментом сучасного соціального контролю.

\section{Бібліографічний список:}

1. Ягунов Д. «Malleus Maleficarum» of modern society: preconditions and prevalence of torture in XXI century and the policy of combating torture. Вісник Донеиького наџіонального університету імені Василя Стуса. Серія Політичні науки, 2020. 5. С. 58-97.

2. Диса К. Історія з відьмами. Суди про чари в українських воєводствах Речі Посполитої XVII-XVIII століття. Київ: Критика, 2008. 304 с.

3. Were 50 Million People Really Killed in the Inquisition? URL: www.ncregister.com/blog/were-50-millionpeople-really-killed-in-the-inquisition

4. Peters E. Inquisition. Berkeley: University of California Press, 1989.

5. Beaumont D. The Spanish Inquisition: Debunking the Legends. URL: www.strangenotions.com/spanishinquisition

6. Historians say Inquisition wasn't that bad. URL: www.theguardian.com/world/2004/jun/16/

7. Tracy L. Torture and Brutality in Medieval Literature. Negotiations of National Identity. Rochester, NY, 2002. $326 \mathrm{p}$.

8. Lea H. A History of the Inquisition of the Middle Ages. In Three Volumes. Vol. II. New York: Harper \& Brothers, Franklin Square, 1888. 587 p.

9. Greer S. Is the Prohibition against Torture, Cruel, Inhuman and Degrading Treatment Really 'Absolute' in International Human Rights Law? Human Rights Law Review, 2015. 15. P. 7-37.

10. Ягунов Д. Паноптизм і пенальні практики суспільства Постмодерну. Вісник Львівського університету. Філософсько-політичні студії, 2020. Вип. 30. С.240-249/

11. Ягунов Д. Пунітивне місто постмодерну: до питання про дисперсію соціального контролю у XXI столітті. Політичне життя, 2020. Вип. 3. С. 34-50. 
12. Фуко М. Рождение биополитики. Курс лекций, прочитанных в Коллеж де Франс в 1978 - 1979 учебном году. СПб.: Наука, 2010. 448 с.

13. Amnesty poll finds $29 \%$ say torture can be justified. URL: www.bbc.com/news/uk-27387040

14. Кобзін Д., Черноусов А., Щербань С., Батчаєв В. Оцінка масштабів незаконного застосування сили в поліції України у 2018 році. URL: www.khpg.org/1561465967

15. Національний моніторинг незаконного насильства в поліції в 2020 році. Авторський колектив:

Д. Кобзін, А. Черноусов, С. Щербань. Харків, Харківський інститут соціальних досліджень, 2020. 64 с.

16. Ритцер Дж. Современные социологические теории. 5-е изд. СПб.: Питер, 2002. 688 с.

17. Bagaric M., Clarke J. Not Enough Official Torture in the World? The Circumstances in Which Torture Is

Morally Justifiable. University of San Francisco Law Review, Spring 2005. P. 581-616.

18. Ягунов Д. Пенітенціарна політика як складова соціального контролю. Одеса: Фенікс, 2020. 674 с.

19. Tainted by Torture. Examining the Use of Torture Evidence. A report by Fair Trials and REDRESS,

May 2018. 75 p.

20. Einolf C. The Fall and Rise of Torture: A Comparative and Historical Analysis. Sociological Theory, June 2007. 25. 2.

21. Rusche G., Kirchheimer O. Punishment and Social Structure. New York: Columbia University Press, 1933.

22. National Assistance Act 1948. URL: www.legislation.gov.uk/ukpga/Geo6/11-12/29

23. «Lacatus v. Switzerland», application № 14065/15, judgment 19.01.2021

24. Blakeley R. Why torture? Review of International Studies, 2007. 33.

\section{References:}

1. Yagunov D. «Malleus Maleficarum» of modern society: preconditions and prevalence of torture

in XXI century and the policy of combating torture. Visnyk Donetskoho natsionalnoho universytetu imeni Vasylia Stusa. Seriia Politychni nauky, 2020. 5. S. 58-97.

2. Dysa K. Istoriia z vidmamy. Sudy pro chary v ukrainskykh voievodstvakh Rechi Pospolytoi

XVII-XVIII stolittia. Kyiv: Krytyka, 2008. 304 s.

3. Were 50 Million People Really Killed in the Inquisition? URL: www.ncregister.com/blog/were-50-millionpeople-really-killed-in-the-inquisition

4. Peters E. Inquisition. Berkeley: University of California Press, 1989.

5. Beaumont D. The Spanish Inquisition: Debunking the Legends. URL: www.strangenotions.com/spanishinquisition

6. Historians say Inquisition wasn't that bad. URL: www.theguardian.com/world/2004/jun/16/

7. Tracy L. Torture and Brutality in Medieval Literature. Negotiations of National Identity. Rochester, NY, 2002. $326 \mathrm{p}$.

8. Lea H. A History of the Inquisition of the Middle Ages. In Three Volumes. Vol. II. New York: Harper \& Brothers, Franklin Square, 1888. 587 p.

9. Greer S. Is the Prohibition against Torture, Cruel, Inhuman and Degrading Treatment Really 'Absolute' in International Human Rights Law? Human Rights Law Review, 2015. 15. P. 7-37.

10. Yagunov D. Panoptyzm i penalni praktyky suspilstva Postmodernu. Visnyk Lvivskoho universytetu. Filosofsko-politychni studii, 2020. Vyp. 30. S.240-249/

11. Yahunov D. Punityvne misto postmodernu: do pytannia pro dyspersiiu sotsialnoho kontroliu u KhKhI stolitti. Politychne zhyttia, 2020. Vyp. 3. S. 34-50.

12. Fuko M. Rozhdenye byopolytyky. Kurs lektsyi, prochytannыkh v Kollezh de Frans v 1978 - 1979 uchebnom hodu. SPb.: Nauka, 2010. 448 s.

13. Amnesty poll finds $29 \%$ say torture can be justified. URL: www.bbc.com/news/uk-27387040

14. Kobzin D., Chernousov A., Shcherban S., Batchaiev V. Otsinka masshtabiv nezakonnoho zastosuvannia syly v politsii Ukrainy u 2018 rotsi. URL: www.khpg.org/1561465967

15. Natsionalnyi monitorynh nezakonnoho nasylstva v politsii v 2020 rotsi. Avtorskyi kolektyv: D. Kobzin,

A. Chernousov, S. Shcherban. Kharkiv, Kharkivskyi instytut sotsialnykh doslidzhen, 2020. $64 \mathrm{~s}$.

16. Ryttser Dzh. Sovremennыe sotsyolohycheskye teoryy. 5-e yzd. SPb.: Pyter, 2002. 688 s.

17. Bagaric M., Clarke J. Not Enough Official Torture in the World? The Circumstances in Which Torture Is

Morally Justifiable. University of San Francisco Law Review, Spring 2005. P. 581-616.

18. Yahunov D. Penitentsiarna polityka yak skladova sotsialnoho kontroliu. Odesa: Feniks, 2020. 674 s.

19. Tainted by Torture. Examining the Use of Torture Evidence. A report by Fair Trials and REDRESS, May 2018. 75 p.

20. Einolf C. The Fall and Rise of Torture: A Comparative and Historical Analysis. Sociological Theory, June 2007. 25. 2.

21. Rusche G., Kirchheimer O. Punishment and Social Structure. New York: Columbia University Press, 1933.

22. National Assistance Act 1948. URL: www.legislation.gov.uk/ukpga/Geo6/11-12/29

23. «Lacatus v. Switzerland», application № 14065/15, judgment 19.01.2021

24. Blakeley R. Why torture? Review of International Studies, 2007. 33. 


\section{Yagunov D. V. Torture as a tool of modern social control policy}

The article is focused on research of the phenomenon of torture in the XXI century. In the article, the author presents a thesis that explains not only the resumption of torture as a phenomenon in the second half of the XX century but also spreading of the phenomenon of torture in the XXI century with corresponding dispersal of social control networks and, consequently, increasing of types and kinds of deviants. Thus, on the one hand, national criminal justice systems cannot cope with this task - to deal with deviants only within the formal procedures enshrined in national law against the background of increasing classes, types, types and, consequently, the number of deviants. On the other hand, we have the data of numerous studies and surveys of the population of Europe and North America, where from 1/3 to 1/2 of citizens allow the use of torture against terrorists for the purpose of the same "security". The article concludes that the policy of preventing torture and combating social practices of torture in the XXI century is a reflection of a complex political dualistic process: an attempt to develop more "secure society" with corresponding failure to "secure" it. The article analyzes the models that explain the political preconditions for the use of torture in the second half of the XX - early XXI century for the purposes of "protection of society". Thus, scientists distinguish three models: 1) "security model"; 2) "stability model"; 3) "legitimation model". The article emphasizes that in the society of the XXI century torture exists within two interrelated political spheres, where the first of the spheres is a formalized policy of combating torture, which is shaped and implemented within universal regional and national structures. The second one is informal torture policy, which is shaped within the framework of post-modern modulation of panoptic risk management, where torture is an instrument of modern social control.

Key words: torture, ill-treatment, European Court of Human Rights, European Convention on Human Rights, Committee for the Prevention of Torture, Council of Europe, enhanced techniques of interrogation, prevention of torture, investigation of torture, preconditions for torture in the XXI century. 